\title{
PRIORITAS PERMASALAHAN PENGELOLAAN KEUANGAN DESA PADA DESA/NEGERI DI KOTA AMBON, MALUKU
}

\section{PROBLEM PRIORITY OF VILLAGE FINANCIAL MANAGEMENT ON VILLAGES IN AMBON CITY, MALUKU}

\author{
Galih Kurniawan Sidik¹, Achmad Djazuli² \\ ${ }^{1}$ Institut Agama Islam Tazkia - Bogor \\ 2 Institut Agama Islam Tazkia - Bogor \\ Email : galih@tazkia.ac.id
}

\begin{abstract}
ABSTRAK
Undang-Undang Nomor 6 Tahun 2014 mengamanahkan Pemerintah Desa untuk dapat mengelola keuangannya secara efektif. Akan tetapi, pada pelaksanaannya, pengelolaan keuangan desa masih belum efektif. Tujuan dari penelitian ini adalah untuk menganalisis prioritas permasalahan pada pengelolaan keuangan desa/negeri di Kota Ambon, Provinsi Maluku. Metode yang digunakan adalah Analytic Network Process (ANP). Hasil analisis pada penelitian ini menunjukkan bahwa subkultur kekuasaan menjadi variabel permasalahan yang paling dominan pada pengelolaan keuangan desa/negeri Kota Ambon. Selain itu, berdasarkan hasil analisis juga dapat diketahui bahwa variabel-variabel yang memiliki pengaruh lebih besar adalah: sub kultur kekuasaaan, sub kultur ekonomi, adanya rencana pembangunan desa secara periodik, adanya regulasi yang tertata dengan baik, sub kultur sosial, adanya pengelolaan BUMDesa yang efektif, serta adanya kemitraan dengan dunia usaha (swasta).
\end{abstract}

Kata Kunci : ANP, efektifitas, keuangan desa, tata kelola

\section{ABSTRACT}

Law No. 6 of 2014 mandates the Village Government to be able to manage its finances effectively. However, in its implementation, village financial management is still not effective. The purpose of this study is to analyze priority problems in village / state financial management in Ambon City, Maluku Province. The method used is the Analytic Network Process (ANP). The results showed that the power subculture is the most dominant problem variable in Ambon City's village / village financial management. In addition, based on the results of the analysis it can also be seen that the variables that have a greater influence are: the power sub-culture, the economic sub-culture, the existence of periodic village development plans, the existence of well-ordered regulations, social sub-culture, the existence of BUMDesa management which effective, as well as partnerships with the business (private).

Keywords : ANP, effectiveness, governance, villages financial. 


\section{PENDAHULUAN}

Berdasarkan Undang-Undang (UU) Nomor 6 Tahun 2014 tentang Desa, disebutkan bahwa desa dan desa adat atau yang disebut dengan nama lain, adalah kesatuan masyarakat hukum yang memiliki batas wilayah yang berwenang untuk mengatur dan mengurus urusan pemerintahan, kepentingan masyarakat setempat berdasarkan prakarsa masyarakat, hak asal usul, dan/atau hak tradisional yang diakui dan dihormati dalam sistem pemerintahan Negara Kesatuan Republik Indonesia. Beberapa peraturan pelaksanaan atas UU Nomor 6 Tahun 2014 telah diterbitkan, baik berupa peraturan pemerintah (PP), Peraturan Menteri, Peraturan Bupati/Walikota. Beberapa peraturan yang diterbitkan oleh Kementerian Dalam Negeri adalah Peraturan Menteri Dalam Negeri (Permendagri) Nomor 111 Tahun 2014 tentang Pedoman Teknis Peraturan di Desa, Permendagri Nomor 112 Tahun 2014 tentang Pemilihan Kepala Desa, Permendagri Nomor 113 Tahun 2014 yang telah diganti dengan Permendagri Nomor 20 Tahun 2018 tentang Pengelolaan Keuangan Desa, Permendagri Nomor 114 Tahun 2014 tentang Pedoman Pembangunan Desa, Permendagri Nomor 83 Tahun 2015 tentang Pengangkatan dan Pemberhentian Perangkat Desa, Permendagri Nomor 84 Tahun 2015 tentang Susunan Organisasi dan Tata Kerja Pemerintah Desa, Permedagri Nomor 1 Tahun 2016 tentang Pengelolaan Aset Desa, Permendagri Nomor 14 Tahun 2016 tentang Perubahan Kedua Atas Peraturan Menteri Dalam Negeri Nomor 32 Tahun 2011 tentang Pedoman Pemberian Hibah dan Bantuan Sosial Yang Bersumber Dari Anggaran Pendapatan dan Belanja Daerah.

Sejalan dengan tuntutan dinamika pembangunan bangsa, perlu dilakukan pembangunan kawasan perdesaan. Pembangunan kawasan perdesaan merupakan perpaduan antar desa dalam satu kabupaten/kota sebagai upaya mempercepat dan meningkatkan kualitas pelayanan, pembangunan, dan pemberdayaan masyarakat desa di kawasan perdesaan melalui pendekatan pembangunan partisipatif (Aziz, 2016; Elvina dan Musdhalifah, 2019). Oleh sebab itu, perencanaan pembangunan kawasan perdesaan dibahas bersama antara pemerintah provinsi, pemerintah kabupaten/kota dan pemerintah desa.

Dalam melaksanakan pembangunan desa dan kawasan perdesaan tersebut diperlukan sumber pendanaan/pendapatan desa. Desa mempunyai sumber pendapatan desa yang terdiri atas pendapatan asli desa, bagi hasil pajak daerah dan retribusi daerah kebupaten/kota, bagian dari dana perimbangan keuangan pusat dan daerah yang diterima oleh kabupaten/kota, alokasi anggaran dari Anggaran Pendapatan dan Belanja Negara (APBN), bantuan keuangan dari Anggaran Pendapatan dan Belanja Daerah (APBD) Provinsi dan APBD Kabupaten/Kota, serta hibah dan sumbangan tidak mengikat dari berbagai pihak.

Bantuan keuangan dari APBD Provinsi dan APBD Kabupaten/Kota diberikan berdasarkan kemampuan keuangan pemerintah daerah. Sumber pendapatan lain yang dapat diusahakan oleh desa berasal dari Badan Usaha Milik Desa (BUMDesa), pengelolaan pasar desa, pengelolaan kawasan wisata skala desa, pengelolaan tambang mineral bukan logam dan tambang batuan dengan tidak menggunakan alat berat, serta sumber lainnya dan tidak untuk diperjualbelikan.

Sayangnya, optimalisasi sumber-sumber pendapatan tersebut oleh pemerintahan desa belum banyak dilakukan. Hampir seluruh pendapatan desa masih berasal dari bantuan keuangan APBD Kabupaten/Kota dalam bentuk Alokasi Dana Desa (ADD) dan Bagi Hasil Pajak dan Retribusi, serta alokasi anggaran pemerintah pusat melalui APBN, yang disebut dengan Dana Desa. Hanya sebagian kecil berasal dari masyarakat maupun bantuan pihak swasta serta pendapatan asli desa. 
Dalam konsep "desa membangun", pemerintah desa didorong untuk mampu menyelenggarakan pembangunan desa yang terencana dalam Anggaran Pendapatan dan Belanja Desa (APBDesa). Dalam konsep ini, pemerintahan desa diminta untuk mengidentifikasi seluruh sumber pendapatan desa, seperti yang disebutkan di atas, dan merencanakan penggunaan dana-dana tersebut untuk memenuhi kebutuhan masayarakat desa, menggali dan mengembangkan keunggulan komparatif dan kompetitif masing-masing desa, yang pada akhirnya dapat menyejahterakan masyarakat desa.

Namun demikian, fakta sampai dengan saat ini masih menunjukkan pemerintahan desa belum sepenuhnya memahami dan mampu menyusun APBDesa. Terdapat kemungkinan APBDesa yang disusun belum mencerminkan keinginan/kebutuhan desa yang sesungguhnya. Menurut Permendagri Nomor 114 Tahun 2014 tentang Pedoman Pembangunan Desa, penyusunan APBDesa berdasarkan pada RKP Desa yang sudah sinkron dengan RPJM Desa dan RPJM Kabupaten/Kota. Permasalahan yang muncul adalah periode RPJM Desa yang ada tidak selalu sesuai dengan program pembangunan desa yang diamanatkan aturan-aturan pelaksanaan dari UU Nomor 6 Tahun 2014, terutama terkait dengan prioritas penggunaan dana desa.

Di samping itu, tidak semua desa melakukan revisi (perubahan) RPJM Desa pasca terbitnya UU tersebut. Desa/negeri di wilayah Kota Ambon misalnya, memiliki periodisasi RPJM Desa 2011-2016, dan saat dana desa disalurkan desa/negeri tidak melakukan revisi program dalam RPJM Desa maupun RKP Desa. Dalam proses penyusunan RPJM Desa dan RKP Desa peran pemerintah Kota Ambon lebih dominan, karena Kepala Desa (Bapa/lbu Raja) dan BPD (Saniri) memiliki kemampuan dan pengetahuan yang terbatas dalam penyusunan perencanaan pembangunan desa.

Dalam periode tahun 2015-2018, pemerintah sudah merealisasikan dana desa yang terus meningkat, yaitu sebesar Rp20,80 Trilyun pada Tahun 2015, sebesar Rp46,70 Trilyun pada Tahun 2016, sebesar Rp60,00 Trilyun pada Tahun 2017, dan sebesar Rp60,00 Trilyun pada Tahun 2018. Sementara untuk Tahun 2019, pemerintah sudah mengalokasikan anggaran sebesar Rp70,00 Trilyun.

Tujuan penggunaan dana desa yang telah ditetapkan sesuai ketentuan, seharusnya dapat menjamin bahwa meningkatnya penyaluran dana desa ke desa seharusnya dapat meningkatkan pelayanan publik di desa, mengurangi kemiskinan di desa secara signifikan, memajukan perekonomian desa, mengatasi kesenjangan pembangunan antar desa yang selama ini masih terjadi, dan pada akhirnya dapat memperkuat masyarakat desa sebagai subyek pembangunan seperti yang dikehendaki dalam nawacita. Pengelolaan keuangan desa (termasuk dana desa sebagai porsi terbesar saat ini) secara efektif harus diterapkan guna mendorong tercapainya tujuan tersebut.

Penggunaan seluruh pendapatan desa, termasuk dana desa dan ADD, harus dipertanggungjawabkan oleh pemerintahan desa secara akuntabel. Namun dalam prakteknya, masih banyak ditemukan permasalahan-permasalahan terkait pengelolaan dana desa, antara lain: dalam tataran input, proses dan output terdapat permasalahan pengalokasian dana desa per desa tidak sesuai dengan formulasi sesuai ketentuan, penyaluran dana desa dari Rekening Kas Umum Daerah (RKUD) ke Rekening Kas Desa (RKD) terlambat, terdapat Pemerintah Kabupaten/Kota yang menetapkan syarat tambahan atas penyaluran dana desa, penggunaan dana desa dan ADD yang tidak sesuai peruntukan, realisasi dana desa tidak dapat dipertanggungjawabkan, korupsi dana desa oleh Kepala Desa/Perangkat Desa, penunjukkan pendamping desa oleh Pemerintah Provinsi tidak sesuai ketentuan, perangkat desa tidak 
melakukan fungsinya untuk melakukan bimbingan ke desa-desa, realisasi dana desa tidak melibatkan/memberdayakan masyarakat setempat, dan seterusnya.

Permasalahan-permasalahan tersebut mengindikasikan pemerintahan desa, yang sejak awal merupakan community self governance (Aziz 2016), sebenarnya belum cukup siap untuk menjalankan tugas dan fungsi layaknya sistem pemerintahan otonomi daerah yang ada di kabupaten/kota. Banyaknya pengaturan yang diterbitkan oleh pemerintah pusat maupun pemerintah daerah juga mengancam sifat sosial komunitas desa yang seharusnya memiliki kebebasan dalam menentukan dan memenuhi kebutuhannya. Outcome dari pengelolaan keuangan desa, sejak dimulainya penyaluran dana desa langsung ke desa untuk melakukan pembangunan, yaitu meningkatkan kesejahteraan masyarakat desa juga belum terlihat secara nyata. Berdasarkan uraian-uraian tersebut, maka rumusan masalah pada penelitian ini adalah bagaimana prioritas permasalahan pada pengelolaan keuangan desa/negeri di Kota Ambon Provinsi Maluku.

\section{LANDASAN TEORI}

Adisasmita (2011:35) mendefinisikan "pengelolaan keuangan daerah adalah keseluruhan kegiatan yang meliputi perencanaan, pelaksanaan, penatausahaan, pelaporan, pertanggungjawaban dan pengawasan". Menurut Permendagri Nomor 113 Tahun 2014 tentang Pengelolaan Keuangan Desa, sebagaimana telah diubah dengan Permendagri Nomor 20 Tahun 2018, disebutkan bahwa tahapan Pengelolaan Keuangan Desa meliputi perencanaan, penganggaran, penatausahaan, pelaporan, pertanggungjawaban, serta pembinaan dan pengawasan. Efektivitas pengelolaan keuangan desa dipengaruhi oleh efektivitas proses perencanaan pembangunan desa, dimana desa harus mampu secara jelas menetapkan tujuannya dan strategi pencapaian tujuan tersebut. Mengingat kondisi aparatur pemerintahan desa, pada saat penelitian ini dilakukan, yang masih minim pengetahuan dan kemampuan dalam penyelenggaraan administrasi pemerintahan maupun pembangunan, maka pembinaan dan pengawasan dari pemerintah provinsi maupun pemerintah kabupaten/kota sangat diperlukan.

Perencanaan keuangan desa harus sejalan dengan proses perencanaan pembangunan desa berdasarkan Rencana Pembangunan Jangka Menengah (RPJM) Desa dan Rencana Kerja Pemerintah (RKP) Desa. Permendagri 114 Tahun 2014 tentang Pedoman Pembangunan Desa menjelaskan setidaknya penyusunan RPJM Desa harus disusun dengan mengikutsertakan unsur masyarakat desa dan dengan mempertimbangkan kondisi obyektif desa dan prioritas program dan kegiatan kabupaten/kota.

Skema pengelolaan keuangan desa berdasarkan Adisasmita (2011:35) dan Permendagri 20 Tahun 2018 dapat digambarkan pada Gambar 1 sebagai berikut: 


\section{Gambar 1 Skema Analisa Pengelolaan Keuangan Desa}

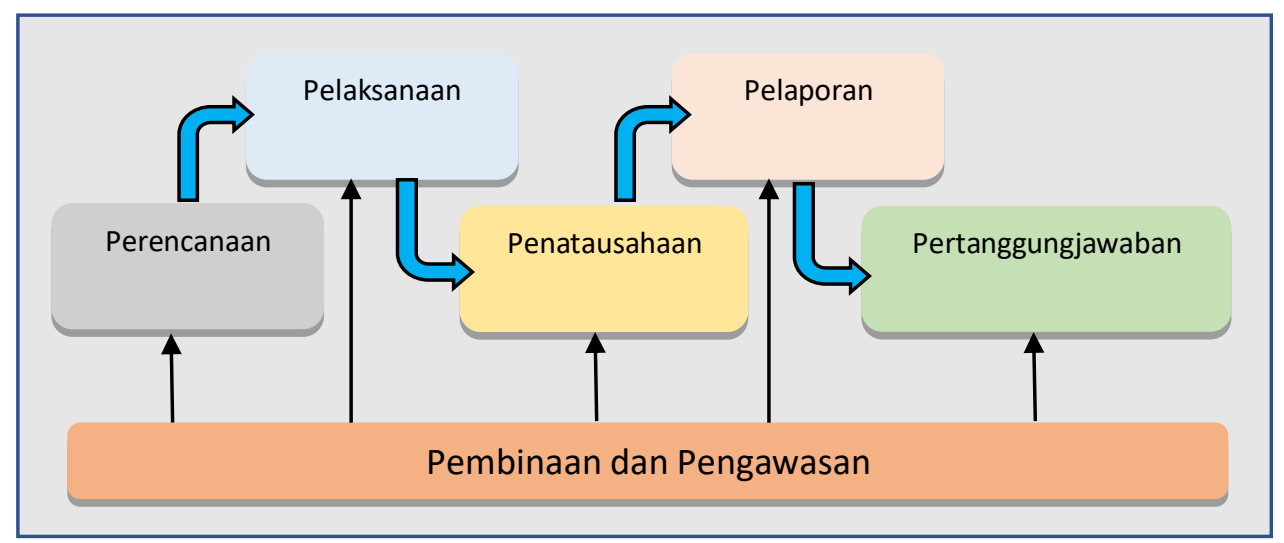

Sumber: Diolah dari Adisasmita (2011:35) dan Permendagri Nomor 20 Tahun 2018

Pelaksanaan keuangan desa harus dipertangungjawabkan oleh pengelola keuangan desa. Dalam konteks ini, Kepala Desa menyampaikan laporan pertanggungjawaban realisasi pelaksanaan APBDesa, yang terdiri dari pendapatan, belanja, dan pembiayaan, kepada Bupati/Walikota setiap akhir tahun anggaran. Laporan pertanggungjawaban realisasi pelaksanaan APBDesa tersebut dilampiri Format Laporan Pertanggungjawaban Realisasi Pelaksanaan APBDesa Tahun Anggaran berkenaan, Format Laporan Kekayaan Milik Desa per 31 Desember Tahun Anggaran berkenaan, dan Format Laporan Program Pemerintah dan Pemerintah Daerah yang masuk ke Desa, untuk ditetapkan dengan Peraturan Desa.

Pembinaan dan pengawasan keuangan desa dilakukan oleh pemerintah provinsi dan pemerintah kabupaten/kota. Pemerintah Provinsi wajib membina dan mengawasi pemberian dan penyaluran Dana Desa, Alokasi Dana Desa, dan Bagi Hasil Pajak dan Retribusi Daerah dari Kabupaten/Kota kepada Desa, sedangkan Pemerintah Kabupaten/Kota wajib membina dan mengawasi pelaksanaan pengelolaan keuangan desa.

\section{METODOLOGI PENELITIAN}

Metode yang digunakan pada penelitian ini adalah menggunakan Analytic Network Process (ANP). ANP merupakan salah satu metode dalam pengambilan keputusan berdasarkan banyak kriteria (Multiple Criteria Decision Making - MCDM) yang dikembangkan oleh Thomas L Saaty (2008:85). Metode ini merupakan pendekatan baru pada metode kualitatif yang merupakan perkembangan dari metode Analytic Hierarchy Process (AHP). Kelebihan ANP adalah metode pengambilan keputusan yang prosesnya sederhana sehingga dapat digunakan dalam masalah yang kompleks. Menurut Ascarya (2012) secara umum ada tiga tahapan dalam metode ANP, yang dijelaskan sebagai berikut:

1. Konstruksi Model, mengingat penelitian ini menggunakan metode kualitatif, maka fase pertama ANP dihasilkan dari metode penelitian kualitatif yang kemudian dikonfirmasi kepada pakar yang merupakan narasumber dari penelitian ini.

2. Kuantifikasi Model, dalam fase ini digunakan kuesioner dengan 9-Point Numeric Scala Rating. Data kuesioner ditabulasi dalam aplikasi excel kemudian diinput dalam aplikasi Super Decision yang digunakan dalam analisis ANP. Menurut Ascarya kuesioner 
yang berasal dari setiap narasumber diinput pada jaringan ANP tersendiri. Hasil tabulasi dan input akan menghasilkan supermatriks beserta koefisien eigen vector-nya.

3. Analisa Hasil, dengan digunakannya responden atau narasumber maka perlu dicari kecenderungan jawaban dari para responden tersebut agar tercipta konsesus berupa perbandingan atau pairwise comparasion.

Ketiga tahapan tersebut digambarkan pada Gambar 2 sebagai berikut:

Gambar 2 Tahapan Dalam Metode ANP



Sumber: Ascarya dan Yumanita (2011)

Pada penelitian ini, metode ANP digunakan untuk menganalisis skala prioritas permasalahan pada pengelolaan keuangan desa/negeri di Kota Ambon Provinsi Maluku. Dengan metode ini analisis data mencakup analisis obyek penelitian: (1) menurut sudut pejabat struktural yang terkait dengan pembinaan dan pengawasan pemerintahan dan pembangunan desa, yaitu pejabat pada pemerintahan Provinsi Maluku dan Kota Ambon; (2) menurut sudut pandang pihakpihak yang terlibat langsung dalam pengelolaan keuangan desa, yaitu Kepala Desa (Bapa/lbu Raja), Ketua BPD (Saniri), Sekretaris Desa dan Bendahara Desa; (3) menurut sudut pandang para pemangku kepentingan di desa/negeri, antara lain konsultan/pendamping desa; serta (4) menurut sudut pandang ahli yang relevan dengan obyek yang diteliti.

\section{HASIL DAN PEMBAHASAN}

\section{Hasil Penelitian}

Hasil analisis studi pustaka menghasilkan dekomposisi permasalahan yang dikelompokkan berdasarkan sub kultur dalam teori good governance Pada Tabel 1 berikut:

Hal. 6 
Tabel 1 Dekomposisi Masalah Dalam Metode ANP

Subkultur Teori Elemen

Rincian

\begin{tabular}{|c|c|c|c|}
\hline \multirow[t]{10}{*}{$\begin{array}{l}\text { Subkultur } \\
\text { Kekuasaan }\end{array}$} & \multirow[t]{6}{*}{$\begin{array}{l}\text { Pengelolaan } \\
\text { Keuangan, } \\
\text { Adisasmita } \\
\text { (2011:35), } \\
\text { Permendagri } \\
\text { 113/2014 }\end{array}$} & 1. Perencanaan & $\begin{array}{l}\text { 1. Sinkron dengan RKP } \\
\text { 2. Didukung dengan sumber dana } \\
\text { yang pasti } \\
\text { 3. Menyatakan secara jelas apa } \\
\text { yang akan dilakukan, siapa } \\
\text { yang bertanggungjawab, } \\
\text { bagaimana dilakukan, kapan } \\
\text { dilakukan. } \\
\text { 4. Sistem dan prosedur } \\
\text { perencanaan yang jelas }\end{array}$ \\
\hline & & 2. Pelaksanaan & $\begin{array}{l}\text { 1. Realisasi penerimaan dan } \\
\text { pengeluaran melalui Rekening } \\
\text { Kas Desa } \\
\text { 2. Penerimaan dan pengeluaran } \\
\text { didukung dengan bukti yang sah } \\
\text { 3. Realisasi berdasarkan } \\
\text { APBDesa yang telah disahkan }\end{array}$ \\
\hline & & 3. Penatausahaan & $\begin{array}{ll}\text { 1. } & \text { Tertib } \\
\text { 2. } & \text { Cermat } \\
\text { 3. } & \text { Memiliki pedoman yang jelas }\end{array}$ \\
\hline & & 4. Pelaporan & $\begin{array}{l}\text { 1. Timelines } \\
\text { 2. Transparan (full disclosure) } \\
\text { 3. Informatif } \\
\text { 4. Pedoman yang jelas }\end{array}$ \\
\hline & & 5. Pertanggungjawaban & $\begin{array}{l}\text { 1. Validitas bukti } \\
\text { 2. Kelengkapan bukti } \\
\text { 3. Pedoman pertangqungiawaban }\end{array}$ \\
\hline & & 6. Pembinaan dan Pengawasan & $\begin{array}{l}\text { 1. Memiliki standar/pedoman } \\
\text { 2. Dilakukan oleh orang yang } \\
\text { kompeten } \\
\text { 3. Direcanakan dengan baik } \\
\text { 4. Memberikan feedback } \\
\text { (rekomendasi) untuk perbaikan } \\
\text { 5. Terdapat mekanisme monitoring } \\
\text { tindak lanjut atas rekomendasi }\end{array}$ \\
\hline & $\begin{array}{l}\text { Penataan Regulasi, } \\
\text { DAPP_BAPENAS }\end{array}$ & $\begin{array}{l}\text { Penataan Regulasi dalam } \\
\text { Pembangunan Ekonomi Desa }\end{array}$ & $\begin{array}{l}\text { 1. Terlalu banyak regulasi (hyper } \\
\text { regulation) }\end{array}$ \\
\hline & $(2012)$ & & $\begin{array}{ll}\text { 2. } & \text { Regulasi saling bertentengan } \\
\text { (conflicting) } \\
\text { 3. Tumpang tinding (overlapping) } \\
\text { 4. Multitafsir (multi intepretation) } \\
\text { 5. Tidak taat azas (inconsistency) } \\
\text { 6. Tidak efektif } \\
\text { 7. Menciptakan beban yang tidak } \\
\text { perlu (unnecessary burden) } \\
\text { 8. Menciptakan biaya ekonomi } \\
\text { tinggi (high cost economy) }\end{array}$ \\
\hline & $\begin{array}{l}\text { Rencana } \\
\text { Pembangunan }\end{array}$ & $\begin{array}{l}\text { Rencana Pembangunan Desa } \\
\text { Secara Periodik }\end{array}$ & $\begin{array}{l}\text { 1. Rencana Kerja Pemerintah } \\
\text { Desa (RKP Desa) }\end{array}$ \\
\hline & $\begin{array}{l}\text { Desa, Undang- } \\
\text { Undang Nomor } 6 \\
\text { Tahun } 2014\end{array}$ & & $\begin{aligned} & \text { 2. Rencana Pembangunan Jangka } \text { Menengah Desa (RPJM Desa) } \\
& \text { 3. Rencana Pembangunan Jangka } \\
& \text { Panjang Desa (RKJP Desa) } \\
& \text { 4. Anggaran Pendapatan dan }\end{aligned}$ \\
\hline
\end{tabular}

Hal. 7 


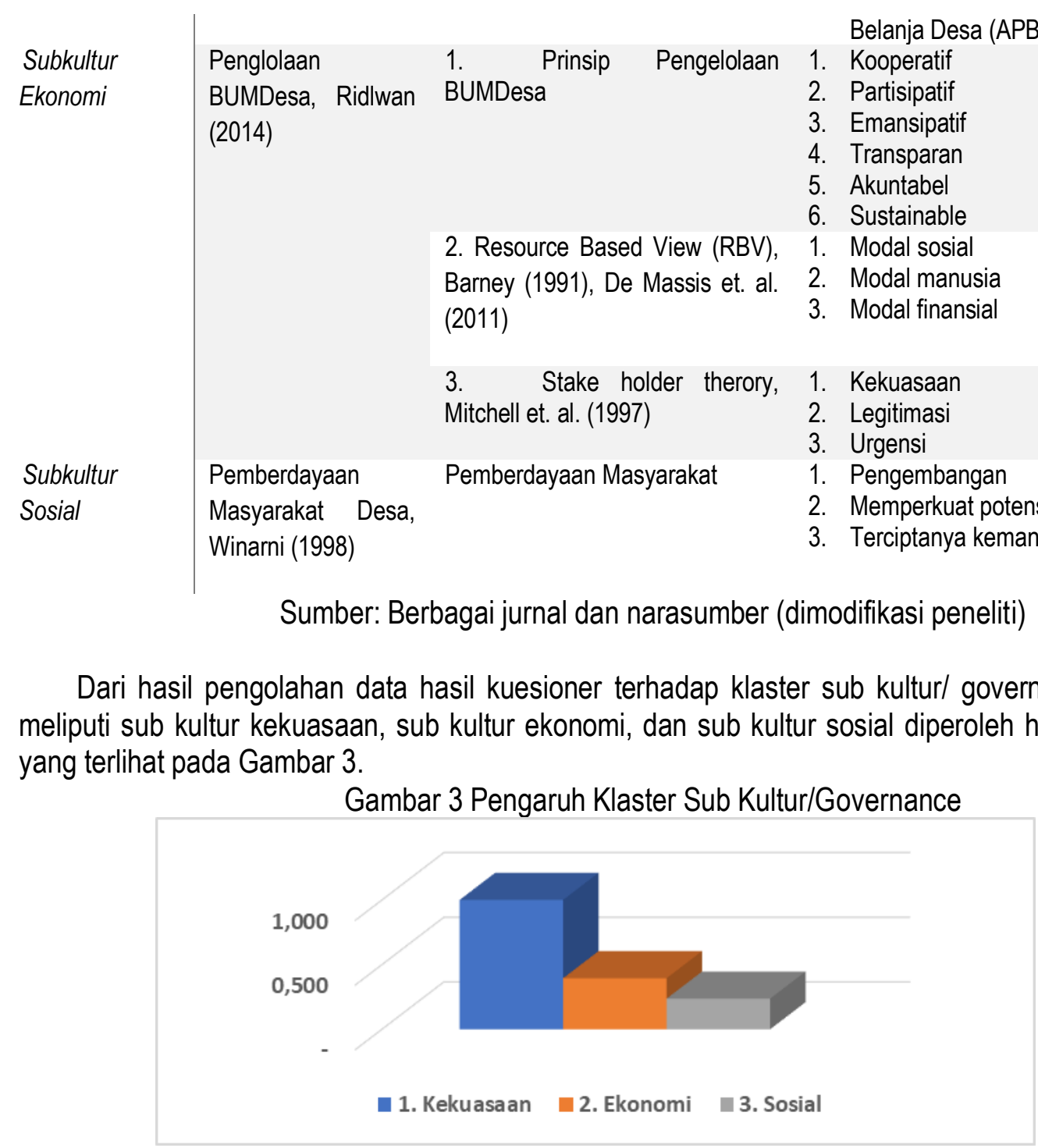

Berdasarkan grafik tersebut, dapat dilihat bahwa para pakar yang menjadi responden pada penelitian ini meyakini bahwa pada tataran sub kultur/governance, faktor kekuasaan menjadi faktor yang saat ini dianggap paling berpengaruh terhadap efektifitas pengelolaan keuangan desa, diikuti oleh faktor ekonomi dan faktor sosial. Hal tersebut mengindikasikan bahwa Pemerintah sebagai regulator harus memperhatikan dan menjadikan Faktor Kekuasaan sebagai prioritas utama dalam upaya meningkatkan efektivitas pengelolaan Keuangan Desa.

Selanjutnya hasil analisa ANP - pada klaster kekuasaan seperti disajikan dalam Gambar 4 di bawah ini terlihat bahwa pada sub klaster Kekuasaan, adanya rencana pembangunan desa secara periodik dianggap menjadi faktor yang paling berpengaruh, diikuti oleh adanya regulasi yang tertata dengan baik dan tata kelola keuangan yang efektif.

Gambar 4 Pengaruh Klaster Kekuasaan 


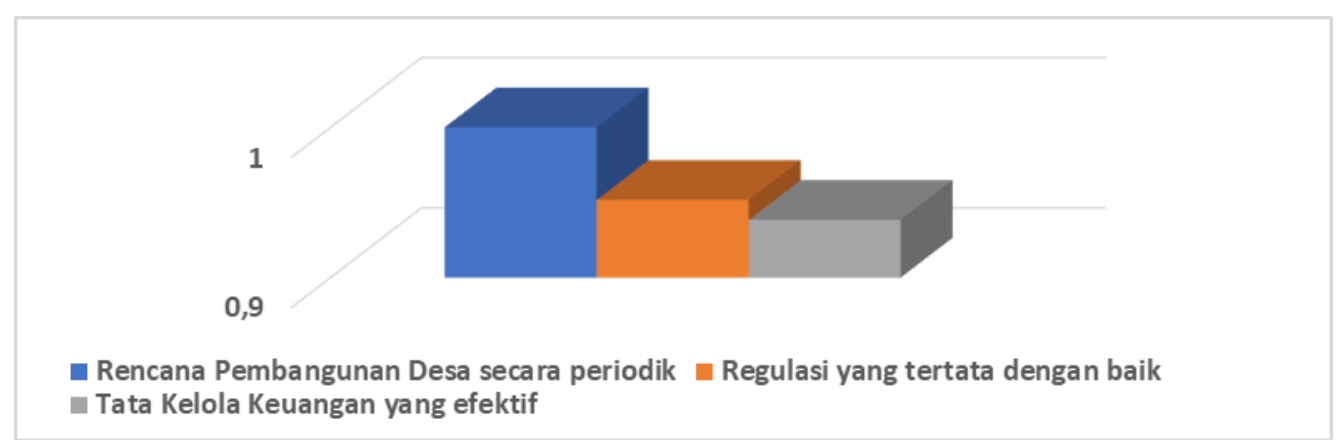

Sedangkan pada subklaster Rencana Pembangunan Desa, hasil pengolahan ANP disajikan dalam Gambar 5 berikut.

\section{Gambar 5 Pengaruh Perencanaan Pembangunan Desa}

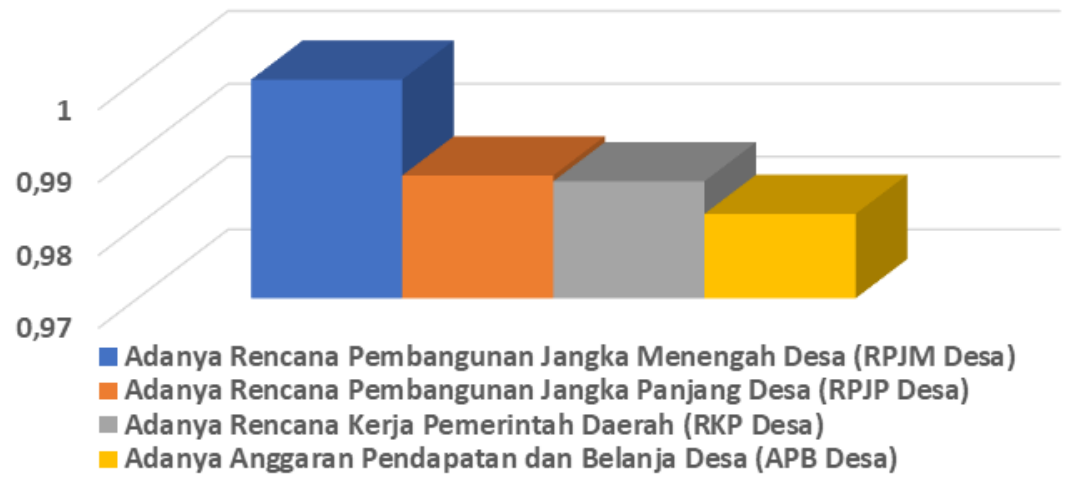

Dalam Grafik diatas terlihat bahwa Adanya Rencana Pembangunan Jangka Menengah Desa (RPJM Desa) dianggap sebagai faktor yang paling berpengaruh dan harus dijadikan sebagai prioritas utama yang harus dibenahi oleh Pemerintah. Jika melihat nilai bobot prioritas dari setiap faktor yang ada pada sub klaster Perencanaan Pembangunan Desa, bobot terkecil adalah Adanya Anggaran Pendapatan dan Belanja Desa sebesar 0,97, selisih antar faktor tersebut sangat kecil. Artinya, para pakar yang menjadi responden pada penelitian ini sepakat bahwa semua faktor pada sub klaster Perencanaan Pembangunan Desa menjadi prioritas yang harus dibenahi.

Selain aspek perencanaan desa, dalam subkultur kekuasaan diungkapkan juga pentingnya sub klaster regulasi yang tertata dengan baik. Hal ini menunjukkan bahwa masyarakat desa/negeri di Kota Ambon memerlukan peraturan terkait dengan pengelolaan keuangan desa yang jelas, lengkap, tidak tumang tindih, tidak bertentangan dengan peraturan lainnya, serta praktis dan mudah dipahami serta dilaksanakan. Dalam sub klaster regulasi yang tertata dengan baik ini hasil ANP yang diperoleh disajikan dalam Gambar 6 berikut.

Gambar 6 Pengaruh Penataan Regulasi 


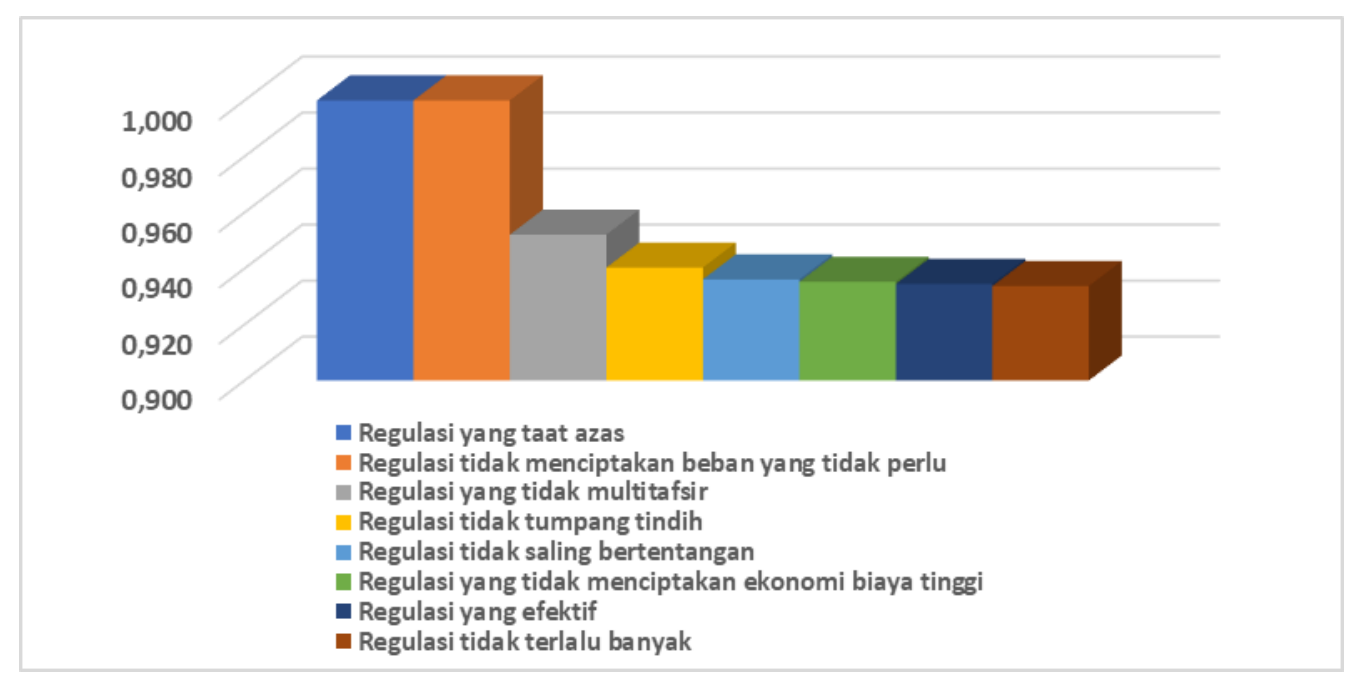

Dari persepsi para pakar yang menjadi responden dalam penelitian ini diperoleh informasi bahwa regulasi yang taat azas dan regulasi yang tidak menciptakan beban yang tidak perlu merupakan dua faktor yang paling mempengaruhi penataan regulasi yang baik. Artinya regulasi yang seharusnya ada hendaknya taat azas (sesuai dengan kaidah-kaidah regulasi) dan tidak menimbulkan beban yang tidak perlu.

Sub Kultur Kekuasaan juga mengidentifikasi faktor tata kelola keuangan yang baik sebagai salah satu faktor yang mempengaruhi upaya meningkatkan kesejahteraan masyarakat desa/negeri di Kota Ambon. Berdasarkan hasil analisis diketahui bahwa faktor pembinaan dan pengawasan yang rekomendasinya dapat ditindaklanjuti, yang memberikan feedback untuk perbaikan, perencanaan keuangan desa yang sinkron dengan RKP, pelaporan keuangan desa yang transparan, dan pengawasan dan pembinaan yang dilakukan oleh orang yang kompeten merupakan faktor-faktor yang memberikan pengaruh terbesar dalam sub klaster tata kelola keuangan desa yang baik.

Variabel-variabel tersebut menunjukkan bahwa tata kelola keuangan desa masih banyak tergantung pada pihak-pihak yang berada di luar struktur pemerintahan desa/negeri yang memiliki tugas dan kewenangan untuk melakukan pembinaan dan pengawasan terhadap pengelolaan keuangan desa/negeri. Peran tersebut dimiliki oleh Pemerintah Pusat, Pemerintah Provinsi Maluku, Pemerintah Kota Ambon termasuk Pendamping Desa.

Selanjutnya dalam sub kultur ekonomi diidentifikasi faktor pengelolaan BUMDesa yang efektif dan kemitraan dengan dunia usaha sebagai dua faktor penting yang berpengaruh terhadap sub kultur ekonomi dalam meningkatkan kesejahteraan masyarakat (Gambar 7)

Gambar 7 Pengaruh Klaster Ekonomi

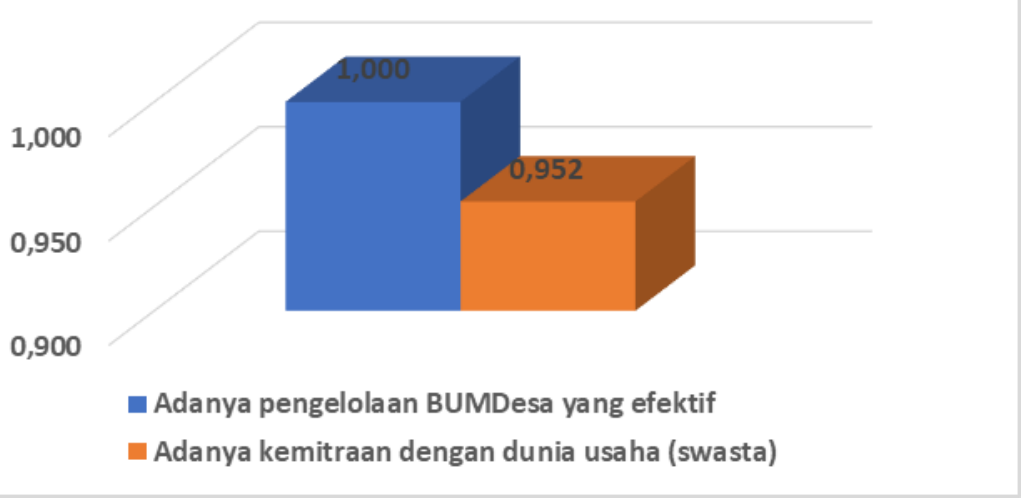


Dari garifk tersebut terlihat bahwa Adanya pengelolaan BUMDesa yang efektif merupakan faktor yang paling berpengaruh dalam sub klaster ekonomi untuk meningkatkan kesejahteraan masyarakat. Namun jika dilihat perbedaan dengan faktor Adanya kemitraaan dengan dunia usaha (swasta), yaitu sebesar 0,05 maka dapat dikatakan bahwa kedua faktor tersebut memiliki dampak yang hampir sama untuk meningkatkan kesejahteraan masyarakat desa/negeri di Kota Ambon.

Untuk mewujudkan BUMDesa yang efektif terdapat variabel yang paling menentukan pengelolaan BUMDesa yaitu pemodalan finansial, yang saat ini didapatkan dari penyertaan modal dari keuangan desa, disamping sumber daya manusia yang belum kompeten.

Selain itu dapat diketahui juga bahwa faktor adanya modal finansial dalam pengelolaan BUMDesa merupakan faktor terpenting, yang menunjukkan bahwa untuk menjalankan BUMDesa secara efektif modal finansial merupakan faktor yang paling diperlukan. Namun tingkat kepentingan faktor ini juga hampir sama besarnya dengan faktor-faktor seperti: Adanya prinsip partisipatif dalam pengelolaan BUMDesa, Adanya modal manusia dalam pengelololaan BUMDesa, serta Adanya prinsip akuntabel dalam pengelolaan BUMDesa. Faktor-faktor tersebut yang diyakini para pakar dalam kuesioner ANP dalam penelitian ini yang paling berpengaruh terhadap efektivitas pengelolaan BUMDesa.

Sementara itu, dalam sub klaster kemitraan dengan pihak swasta hasil pendapat para pakar disajikan dalam Gambar 8. Dengan hasil yang tidak berbeda jauh, prinsip-prinsip yang ditawarkan dalam kemitraan dengan dunis usaha seperti prinsip saling menguntungkan, prinsip saling membesarkan dan prinsip saling membutuhkan merupakan prinsip-prinsip yang penting dalam membina kemitraan antara desa/negeri dengan dunia usaha dalam rangka meningkatkan kesejahteraan masyarakat desa/negeri.

Gambar 8 Pengaruh Kemitraan Dengan Dunia Usaha

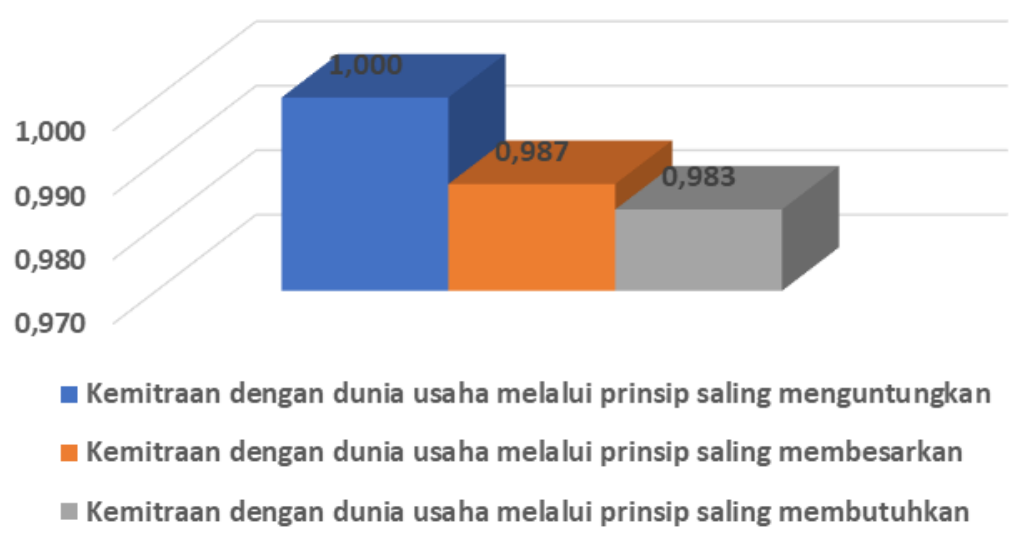

Dalam sub kultur sosial diperoleh informasi bahwa faktor Adanya upaya kemandirian masyarakat dan Adanya Pengembangan Kemampuan Masyarakat diyakini oleh para responden dalam penelitian ini sebagai faktor yang paling mempengaruhi efektivitas pengelolaan keuangan desa dalam meningkatkan kesejahteraan masyarakat. Hasil pengolahan ANP atas sub kultur sosial ini disajikan pada Gambar 9 berikut.

Gambar 9 Pengaruh Klaster Sosial 


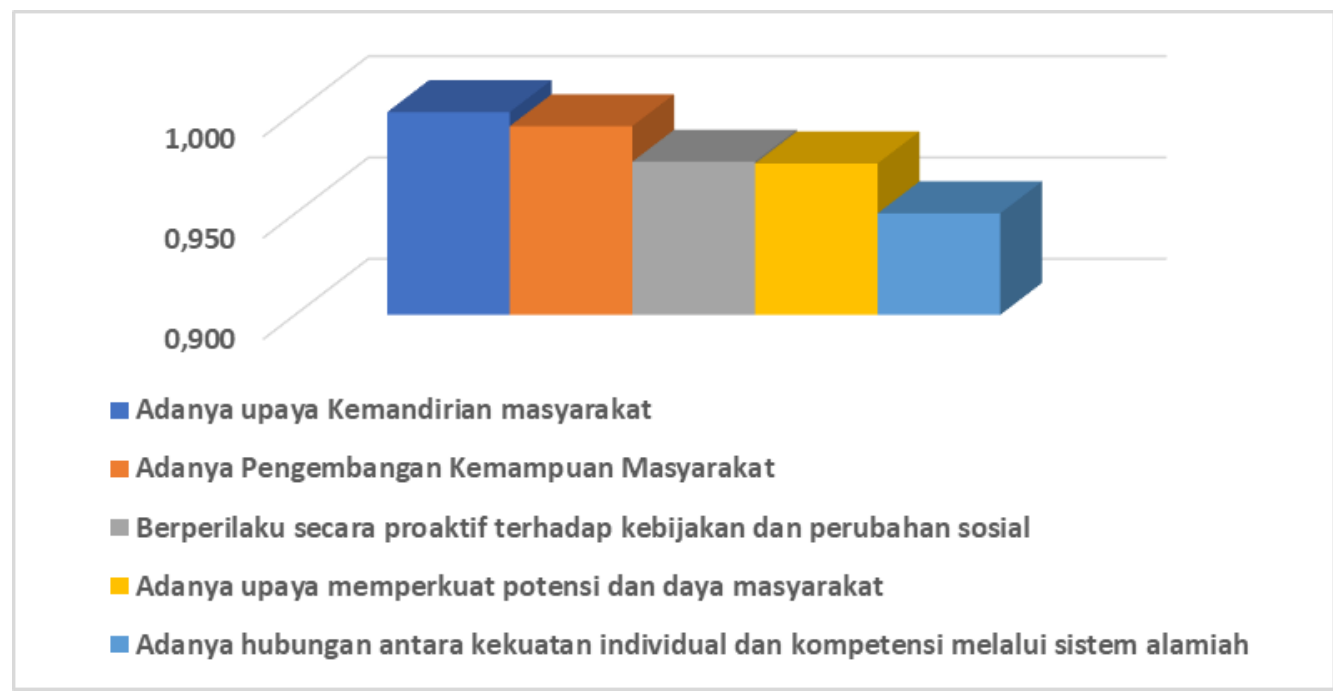

Berdasarkan hasil-hasil tersebut terlihat bahwa variabel-variabel yang memiliki pengaruh lebih besar adalah: sub kultur kekuasaaan, sub kultur ekonomi, adanya rencana pembangunan desa secara periodik, adanya regulasi yang tertata dengan baik, sub kultur sosial, adanya pengelolaan BUMDesa yang efektif, adanya kemitraan dengan dunia usaha (swasta). Dengan demikian, dapat disimpulkan bahwa variabel-variabel tersebut merupakan permasalahan yang dianggap paling memiliki tingkat prioritas yang tinggi.

Terkait sub kultur kekuasaan, dapat dijelaskan bahwa masyarakat desa/negeri di Kota Ambon secara umum masih merupakan masyarakat tradisional, yang mengandalkan intervensi dari sub kultur kekuasaan (Pemerintah Kota Ambon atau Pemerintah Desa/Negeri). Semakin baik sub kultur kekuasaan ini akan semakin penting dampaknya bagi peningkatan kesejahteraan masyarakat desa/negeri.

Terkait dengan sub kultur ekonomi (sektor privat) dapat dijelaskan bahwa variabel ini menunjukkan bahwa peningkatan kesejahteraan masyarakat dapat lebih cepat dicapai bilamana sektor privat juga berpartisipasi. Peningkatan ekonomi ini dilakukan dengan pendekatan ekonomi kerakyatan, yaitu pengembangan dunia usaha berbasis partisipasi masyarakat.

Selanjutnya, adanya perencanaan pembangunan desa secara periodik merupakan variabel penting yang menjelaskan bahwa untuk meningkatkan kesejahteraan masyarakat desa/negeri diperlukan perencanaan pembangunan yang baik dan terjadwal secara periodik. Dengan demikian pengukuran peningkatan kesejahteraan masyarakat desa/negeri dapat dilakukan secara periodik juga.

Adanya tata kelola keuangan yang efektif merupakan variabel penting berikutnya. Hal ini menjelaskan bahwa peningkatan kesejahteraan masyarakat desa/negeri di Kota Ambon dapat dicapai dengan intervensi pemerintahan setempat, partisipasi sektor swasta, perencanaan pembangunan desa secara periodik, regulasi yang tertata dengan baik, serta tata kelola keuangan yang efektif. Efektivitas tata kelola keuangan dijelaskan berdasarkan teori Gibson (1996: 36) yang meliputi kejelasan tujuan, strategi untuk mencapai tujuan, proses analisa dan perumusan kebijakan yang mantap, perencanaan yang matang, penyusunan program yang tepat, ketersediaan sarana dan prasarana yang diperlukan, serta sistem pengawasan dan pengendalian yang bersifat mendidik. 


\section{REKOMENDASI KEBIJAKAN}

\section{Rekomendasi}

Analisis permasalahan pada pengelolaan keuangan desa/negeri di Kota Ambon, Provinsi Maluku pada penelitian ini berdasarkan tiga subkultur yaitu subkultur kekuasaan, subkultur ekonomi, dan subkultur sosial. Berdasarkan hasil analisis diketahui bahwa subkultur kekuasaan menjadi variabel permasalahan yang paling dominan dibandingkan subkultur yang lainnya. Hal ini mengindikasikan bahwa masyarakat desa/negeri di Kota Ambon secara umum masih merupakan masyarakat tradisional, yang mengandalkan intervensi dari sub kultur kekuasaan (Pemerintah Kota Ambon atau Pemerintah Desa/Negeri). Semakin baik sub kultur kekuasaan ini akan semakin penting dampaknya bagi peningkatan kesejahteraan masyarakat desa/negeri. Selain itu, berdasarkan hasil analisis juga dapat diketahui bahwa variabel-variabel yang memiliki pengaruh lebih besar adalah: sub kultur kekuasaaan, sub kultur ekonomi, adanya rencana pembangunan desa secara periodik, adanya regulasi yang tertata dengan baik, sub kultur sosial, adanya pengelolaan BUMDesa yang efektif, serta adanya kemitraan dengan dunia usaha (swasta).

\section{Kebijakan}

Bedasarkan hasil dan interpretasi penelitian ini, maka peneliti memberikan saran sebagai rekomendasi kebijakan yaitu: Peningkatan SDM yang dilakukan untuk dapat menyusun perencanaan pembangunan yang mantap, terwujudnya tata kelola pengelolaan keuangan berdasar prinsip transparan, akuntabel, efektif, efisien, ekonomis, dan disiplin anggaran, pengelolaan BUMDesa yang efektif dan peningkatan kemampuan masyarakat. 


\section{DAFTAR PUSTAKA}

Adisasmita, Rahardjo, 2011, Manajemen Pemerintahan Daerah, Yogyakarta: Graha IImu

Ascarya, 2012. Konsep Dasar ANP: Pendekatan Baru dalam Penelitian Kualitatif. Pusat Pendidikan dan Studi Kebank- sentralan. Bank Indonesia. Jakarta.

Ascarya dan Yumanita D., 2011. Determinan dan persistensi margin perbankan konvensional dan syariah di Indonesia, Working Paper Series No. WP/10/04

Aziz, N. L. L., 2016). The Village Autonomy And The Effectiveness Of Village Fund. Jurnal Penelitian Politik, 13(2), 193-211.

Barney, Jay, 1991. "Firm Resources and Sustained Competitive Advantage", Journal of Management, 1991, Vol. 17, No. 1, 99-120

DAPP-BAPENAS, 2012. Laporan Akhir Koordinasi Strategis Reformasi Regulasi Tahun 2012 Direktorat Analisa Peraturan Perundang-undangan. Kementerian Perencanaan Pembangunan Nasional / Badan Perencanaan Pembangunan Nasional

De Massis, A., Kotlar, J., Frattini, F., Chrisman, J. J., \& Nordqvist, M., 2016. Family governance at work: Organizing for new product development in family SMEs. Family Business Review, 29(2), 189-213

Elvina dan Musdhalifah, 2019. Peningkatan Kesejahteraan Masyarakat melalui Partisipasi dan Implementasi Kebijakan dengan Efektivitas Pembangunan Program Dana Desa sebagai Variabel Intervening. JSHP Vol. 3 Nomor 12019.

Gibson, Ivancevich, Donnelly, 1996. Organisasi: Perilaku, Struktur, Proses, Edisi Kedelapan Jilid Satu, Terjemahan Nunuk Ardiani, Jakarta: Binarupa Aksara

Mitchell, R.K., Agle, B.R., \& Wood, D.J., 1997. Toward a Theory of Stakeholder Identification and Salience: Defining the Principle of who and What Really Counts.

Peraturan Menteri Dalam Negeri (Permendagri) Nomor 111 Tahun 2014 tentang Pedoman Teknis Peraturan di Desa

Peraturan Menteri Dalam Negeri Nomor 112 Tahun 2014 tentang Pemilihan Kepala Desa

Peraturan Menteri Dalam Negeri Nomor 20 Tahun 2018 tentang Pengelolaan Keuangan Desa

Peraturan Menteri Dalam Negeri Nomor 114 Tahun 2014 tentang Pedoman Pembangunan Desa

Peraturan Menteri Dalam Negeri Nomor 83 Tahun 2015 tentang Pengangkatan dan Pemberhentian Perangkat Desa

Peraturan Menteri Dalam Negeri Nomor 84 Tahun 2015 tentang Susunan Organisasi dan Tata Kerja Pemerintah Desa

Peraturan Menteri Dalam Negeri Nomor 1 Tahun 2016 tentang Pengelolaan Aset Desa

Peraturan Menteri Dalam Negeri Nomor 14 Tahun 2016 tentang Perubahan Kedua Atas Peraturan Menteri Dalam Negeri Nomor 32 Tahun 2011 tentang Pedoman Pemberian Hibah dan Bantuan Sosial Yang Bersumber Dari Anggaran Pendapatan dan Belanja Daerah

Ridlwan, Z., 2014. Urgensi Badan USAha Milik Desa (Bumdes) dalam Pembangun Perekonomian Desa. Jurnal Ilmu Hukum, 8(3), 424-440.

Saaty, Thomas L, 2008. Decision Making with the analytic network process, Int.J. Services Sciences, Vol I No. 1

Undang-Undang Nomor 6 Tahun 2014 Tentang Desa

Winarni, Tri, 1998. Memahami Pemberdayaan Masyarakat Desa Partisipatif dalam Orientasi Pembangunan Masyarakat Desa Menyongsong Abad 21: Menuju Pemberdayaan Pelayanan Masyarakat. Yogyakarta: Adita Media 